УДК 338.242.4: 604.6: 338.439.6

DOI: $10.15673 /$ fie.v11i2.1390

\author{
Криницька О.О. \\ кандидат економічних наук, доцент \\ E-mail: krinitskaia@ukr.net \\ ORCID ID: 0000-0002-5616-2418 \\ Ткачук T.I. \\ кандидат економічних наук, доцент \\ кафредра економічної теорії та фрінансово-економічної безпеки \\ Одеська національна академія харчових технологій \\ вул. Канатна, 112, м. Одеса, Україна, 65039 \\ E-mail: etfeb@ukr.net
}

\title{
ОЦІНКА ВПЛИВУ ВИКОРИСТАННЯ ГЕНЕТИЧНО МОДИФІКОВАНОЇ ПРОДУКЦІЇ НА СТАН ПРОДОВОЛЬЧОЇ БЕЗПЕКИ
}

В статті розглядаються економіко-соціальні аспекти впливу генетично модифікованої продукції на стан продовольчої безпеки, зокрема фрізичну і економічну доступність продовольства, пропозицію продовольчих товарів, ціноутворення та умови конкуренції. Аналізуються сутність та причини створення та застосування ГМО, поширення ГМО у світі та окремих країнах і вплив використання генетично модифікованої продукції на продовольчу безпеку. Проаналізовано правову базу та методи державного регулювання генетично модифікованої продукції в різних країнах. Акцентовано увагу на роль транснаціональних монополій у використанні досягнень науково-технічного прогресу, зокрема ГМО. Досліджується вплив використання ГМО на стан конкурентного середовища національних виробників сільськогосподарської продукції. Виявлено такі опосередковані наслідки запровадження у сільськогосподарський оборот ГМ-продукції, як звуження біологічного природного різноманіття, асортименту харчових продуктів, що негативно позначається на умовах життя людини. Обґрунтовується необхідність державного регулювання генетично модифікованої продукції в Україні та наголошено на проблемних питаннях регулювання використання ГМО .

Ключові слова: продовольча безпека, фізична та економічна доступність, генетично модифікована продукція, генетично модифіковані організми (ГМО).

This work is licensed under a Creative Commons Attribution 4.0 International License http://creativecommons.org/licenses/by/4.0/

Постановка проблеми та її зв'язок з важливими науковими та практичними завданнями. Продовольча безпека держави є важливою складовою продовольчої політики. У цьому плані задоволення потреб людини у повноцінному харчуванні має стати стратегічною метою продовольчої політики. Пріоритетними напрямками цієї політики є розвиток власного сільськогосподарського виробництва, переробної та харчової промисловості, аграрної науки, системи державного контролю за якістю продовольства на усіх стадіях його виробництва та споживання; зменшення залежності від імпорту продовольства та факторів його виробництва; зростання експортного потенціалу країни. Одним з проблемних питань у формуванні механізмів розвитку екологічно безпечного довкілля $є$ поширення генетично модифікованих організмів (ГМО).

Аналіз останніх публікацій по проблемі. Чимало вітчизняних науковців аналізують стан та шляхи покращення продовольчого забезпечення населення України, підвищення ефективності аграрного сектору економіки. Серед численних наукових розро- бок подібного спрямування можна виокремити праці таких вчених, як В. Бакуменко, Б. Баласинович, О. Лебединська, Е. Лібанова, М. Латинін, Т. Лозинська, П. Саблук, Ю. Ярошевська. Проблемам використання ГМО присвячують роботи Б. Черняков, Н. Посунько, І. Лупашко-Стальський, А. Гордєєв. В той же час більшість публікацій $з$ питань використання ГМО торкаються в основному наслідків для екологічних, медичних, біологічних, соціальногуманітарних аспектів. Подальшого методологічного забезпечення потребують механізми реалізації комплексу заходів політико-правового, соціальноекономічного, інформаційно-комунікаційного та організаційного характеру, що спрямовані на формування продовольчої безпеки держави та регулювання використання ГМО з метою мінімізації їх негативного впливу на продовольчу безпеку. Це і обумовило мету даного дослідження.

Формулювання цілей дослідження. Метою дослідження є теоретичне обгрунтування необхідності державного регулювання використання ГМО в системі продовольчої безпеки. 
Обрана мета обумовила такі завдання:

- з'ясувати сутність та причини створення, застосування та поширення ГМО у світі та окремих країнах;

- проаналізувати наслідки використання та правову базу державного регулювання генетично модифікованої продукції для забезпечення продовольчої безпеки;

- запропонувати заходи щодо вдосконалення державного контролю використання ГМО.

Виклад основних результатів та їх обгрунтування. Науково - теоретичні основи «генної інженерії» було закладено ще у позаминулому столітті, коли у 1865 р., Г. Мендель у процесі селекції гороху виявив та продемонстрував явище спадковості, заклавши тим самим розвиток нової науки - генетики. А вже витоки генної інженерії рослин лежать в 1977 році, коли сталося відкриття, що дозволило використати грунтовий мікроорганізм Agrobakteriumtumefaciens як знаряддя введення чужих генів в інші рослини [1].

Генетично модифікований організм (ГМО) це організм, генотип якого було змінено за допомогою методів генної інженерії. Генетичні зміни, як правило, здійснюються в наукових та сільськогосподарських цілях. Генетична модифікація відрізняється від природного та штучного мутагенезу саме направленою зміною генотипу. При цьому генетичний матеріал переносять 3 одного організму в інший, використовуючи технологію рекомбінантних ДНК. Якщо при цьому ДНК, яку переносять, походить з іншого виду, отримані організми називають транс генними [2].

Метою створення генетично модифікованих продуктів були такі цілі, як: підвищення врожайності у порівнянні $з$ традиційними культурами; більша адаптивність генномодифікованих культур до екстремальних погодно-кліматичних умов. В результаті генної модифікації рослини будуть містити більшу кількість корисних поживних речовин та вітамінів. Також в результаті генних модифікацій можна вбудовувати в харчові продукти ліки проти хвороб. Так як генномодифіковані рослини більш стійкі до шкідників та хвороб, то це зменшить інтенсивність їх обробки пестицидами та гербіцидами. Продовольство, вироблене за допомогою генетично модифікованих організмів буде дешевим і смачнішим.

Практичне використання ГМО базується на розробках військових США і СРСР під час холодної війни, коли розроблялася нова зброя, яка знищувала б людський потенціал супротивника, залишаючи неушкодженими територію, природні ресурси та виробничий потенціал.

У зв'язку із тим, що більшість розробок у галузі генної інженерії здійснювалися в лабораторіях США, то вони першими почали активно запроваджувати вирощування таких продуктів, починаючи з 80-х років XX століття. Спочатку ніхто не звертав уваги на віддалені наслідки використання такої продукції. Їх розглядали як один із методів інтенсифікації сільськогосподарського виробництва при зростаючих темпах збільшення населення і обмеженості ресурсів землі для виробництва відповідної кількості продуктів харчування. За прогнозами вчених, населення Землі до 2050 р. може досягти 9-11 млрд. осіб, природно виникає необхідність подвоєння, а то й потроєння світового виробництва сільськогосподарської продукції. Для цієї мети генетично модифіковані сорти рослин відмінно підходять - вони стійкі до хвороб і погоди, швидше дозрівають і довше зберігаються, вміють самостійно виробляти інсектициди проти шкідників [3].

Держава повинна забезпечити населення повноцінною їжею для підтримання здорового способу життя, розширеного відтворення робочої сили та розвитку людської особистості. Саме в цьому контексті ми спробуємо з'ясувати - наскільки використання генномодифікованої продукції сприяє чи, навпаки, ускладнює забезпечення продовольчої безпеки. Якщо взяти три найголовніші аспекти продовольчої безпеки, а саме:

- фізичну доступність продовольства;

- економічну доступність;

- якість та повноцінність харчування,

то використання ГМО найбільшим чином впливає на третій аспект, але не тільки, виправданням його запровадження було якраз сподівання на збільшення виробництва сільськогосподарської продукції в умовах голоду та недоїдання. За допомогою ГМО збільшувалась врожайність сільськогосподарських культур, зменшувалися їх втрати та псування при транспортуванні та зберіганні. Це мало підвищити фізичну доступність продовольства. В свою чергу, збільшення врожайності та зменшення втрат, так само, як і скорочення фінансових і трудових витрат, внаслідок більшої опірності шкідникам і хворобам, мали сприяти зменшенню собівартості, а отже і цін, зробивши харчові продукти більш доступними економічно.

Створення і використання генетично модифікованих продуктів стало тенденцією розвитку аграрних та харчових технологій. Сам процес використання ГМО та доцільність їх створення, як відомо, є дискусійним питанням [4]. $С$, як прибічники ГМО, які вважають генну інженерію сучасним та ефективним способом остаточного подолання продовольчої проблеми, від якої потерпало людство на усіх етапах свого існування, так і ті, хто вважає ГМО знаряддям знищення людської цивілізації в такому вигляді, як вона проіснувала вже декілька тисячоліть. Одні наголошують на тому, що генні технології є закономірним результатом науково-технічного прогресу, а другі вказують на суперечливі наслідки науково-технічного прогресу, на необхідність гармонізації між технологічним, технократичним та соціально-економічним боком розвитку науки і технології.

Для нас же дуже важливими є соціальні та економічні наслідки, вплив використання ГМ продукції на продовольчу безпеку. Саме у цьому контексті ми і будемо розглядати позитивні та негативні оцінки. Як вже з'ясовано, продовольча безпека - це фізична та економічна доступність повноцінної, якісної та здорової їжі [5]. 
На наш погляд, досить небезпечним явищем є скорочення кількісного та якісного складу рослинного та тваринного світу, особливо дикорослого. Хоча і серед культурних рослин спостерігається скорочення сортименту, зокрема овочів. Вчені - біологи, екологи вважають це дуже небезпечним, адже скорочується біологічне різноманіття. На протязі тисячоліть саме природний дикоростучий матеріал був джерелом для виведення нових сортів рослин. Їх різноманіття - це надбання і спадок людства.

Показово, що в даний час кількість сортів рослин не збільшується, як цього слід було б очікувати, а зменшується. Так, в США за останнє сторіччя втрачено близько 93\% сортів овочів і фруктів. Виведені гібридні сорти продаються по всьому світу великим оптом - і увага приділяється не різноманітності смакових і цінності поживних якостей, а здатності до тривалого зберігання, тобто на перше місце виходить економічна вигода виробників. Ну а «органічну їжу» можна продавати набагато дорожче, це теж дуже ринково. I все - через культивацію генномодифікованих рослин. По-перше, вони є агресивними в екосистемі, витискають інші рослини, які не мають, так би мовити, імунітету до тих гербіцидів та пестицидів, якими обробляються ГМ культури. Таким чином, витискаються ендемічні та автохтонні види рослин. Таке явище отримало назву генного забруднення.

Проблема біологічного та генетичного різноманіття вкрай актуальна і для України, яка, з одного боку, має значний природний потенціал, а 3 іншого, - потерпає від кризового стану навколишнього середовища.

Посилення монокультурності в аграрному секторі, коли усе більші площі займаються під обмежену кількість генномодифікованих рослин, зменшує харчову базу населення, веде до збіднення раціону, погіршення фізичної та економічної доступності продовольства. Незважаючи на зростання врожайності, людство все ще не вирішило проблему голоду та недоїдання. I головна причина цього - це те, що генні технології контролюють монополії, які використовують розвиток новітніх технологій на свою користь. Так, компанія Монсанто фактично монополізувала ринок насіння, поглинувши більше півсотні інших компаній, активно скуповує та реєструє патенти, отримує доходи не тільки від продажу ГМ насіння, а й від препаратів боротьби зі шкідниками.

Саме фірми-монополісти диктують ціни. За даними Центру продовольчої безпеки США за 1995 2011 pр., вартість вирощування кукурудзи зросла на $205 \%$, сої - більше ніж на $300 \%$, а бавовни - більше ніж на 500\%. Залежність сільгоспвиробників від закордонного постачальника насіння, засобів боротьби зі шкідниками,техніки - це пряма загроза продовольчій незалежності та продовольчій безпеці держави.

Також це веде до банкрутства національних сільгоспвиробників, які не можуть відшкодовувати такі витрати. Внаслідок концентрації виробництва у великих господарствах, залежності від закордонних постачань, зростають ціни на сільськогосподарську сировину та харчові продукти, зменшується рівень доходів населення, а це негативно позначається на продовольчій безпеці.

ГМО зробили своєрідне коло - розпочиналося їх створення з метою знищення людських ресурсів супротивника при збереженні ресурсно-виробничого потенціалу, потім - намагання використати їх для вирішення глобальної продовольчої проблеми. I от - коло замкнулося - ГМО можуть використовуватися, і вже використовуються, як новий вид біологічної зброї. Вже одне це може перекреслити всі аргументи тих, хто вважає безпечним вживання в їжу продукції, яка містить ГМ компоненти.

Офіційно трансгенні технології використовуються з 1996 року. Першими, хто почав активно їх впроваджувати, були США. Потім ними зацікавилися в Канаді, Аргентині, Бразилії. Пізніше використання ГМО просунулося в Індію й Китай. Основними виробниками 3 найбільшими площами, відведеними для цієї мети, є, у першу чергу, США, далі - Аргентина, Канада, Бразилія. Далі йдуть Індія й Китай [6]. Площі сільськогосподарських угідь під генномодифікованими рослинами стрімко зростають. По всіх країнах світу вони становили : у 1996 р. - 2,8 млн. га, у 1999 p. - 40,0 млн. га, у 2003 р. - 67,7 млн. га, у 2006 р. 85,0 млн. га, у 2009p. - 134 млн. га, у 2011 р. - 160 млн. га, у 2014 р. - 180 млн. га.

Позиція Японії щодо використання ГМО може бути зрозуміла $з$ точки зору низького рівня самозабезпеченості країни продовольством, який об'єктивно обумовлюється недостатністю придатних для аграрного виробництва земель і високою щільністю населення, високим рівнем урбанізації. В цих умовах Японія прагне за допомогою генномодифікованої продукції покращити продовольчу незалежність держави.

Такі країни, як Китай та Індія - є одними 3 найбільш густонаселених, проблеми забезпеченості продовольством стоять досить гостро, і використання ГМО представляється таким способом вирішення продовольчої проблеми, який дозволить якнайшвидше отримати результат. Але площі під вирощуванням генномодифікованих рослин у них в 20 разів менше, ніж в США. Що ж стосується країн Латинської Америки, то в переважній більшості їх сільське господарство знаходиться у залежності від діяльності американських аграрних компаній - монополій, які і визначають напрямок його розвитку.

У країнах Свросоюзу ретельно регулюються технології виробництва генномодифікованої продукції. Перш ніж така продукція потрапляє на ринок, вона має пройти перевірку, у ході якої дається оцінка тим ризикам, які вона може завдати здоров'ю людини та стану навколишнього середовища. Тільки після такої комплексної перевірки генномодифікованих продуктів, харчових продуктів і кормів, які містять ГМО, компанії можуть отримати дозвіл на їх вирощування, торгівлю або переробку. Але і після отримання такого дозволу, контроль не припиняється: обов'язковим є моніторинг екологічних ризиків, консультації та надання інформації громадськості [7]. 
Отже у світі, і особливо у Європі, наростає протидія використанню ГМО. Це оформлюється міжнародними правовими актами: в 1997 р. ЮНЕСКО прийняла Декларацію «Людський геном і права людини»; в 1992р. - Конвенцію зі збереження біологічного різноманіття; в 2000 р. Картахенський протокол про біобезпеку - перший міжнародний документ, що регулює розповсюдження ГМ-продукції [8]. В 2005р. прийнятий «Берлінській маніфест», що передбачає створення 100 зон, вільних від ГМО [9].

С країни, в яких нормативно - правовими документами закріплюється принцип добровільного маркування продукції. До них можна віднести Сполучені Штати Америки, Канаду та інші країни Американського континенту. Друга група представлена країнами - членами Свросоюзу, сюди ж можна віднести Австралію, Україну, Росію, які встановлюють принцип примусового маркування, відстеження і моніторингу. Пороговий бар'єр складає в країнах членах Євросоюзу 0,9 \%, така ж норма визначена і в законодавстві України, Росії. В Австралії та Новій Зеландії - 1\%, а в Канаді та Японії - 5\% [10].

На наш погляд, досить небезпечною загрозою для продовольчої безпеки є скорочення кількісного та якісного складу рослинного та тваринного світу, особливо дикорослого. Ще один дуже, на наш погляд, важливий аспект впливу використання ГМО на біорізноманіття, а опосередковано і на продовольчу безпеку - це вплив на комах. 3 одного боку комахишкідники можуть адаптуватися до дії пестицидів i гербіцидів, проти яких стійкі ГМ-продукти, і вижити. А от корисні комахи-запилювачі, корисні грунтові мікроорганізми можуть і зникнути [11].

Розглядаючи поширення генномодифікованої продукції у світі, не можна оминути ту роль, яку відіграють у цьому процесі компанії-виробники харчової продукції та компанії, які виробляють генномодифіковану сировину для харчової промисловості. Світові виробники харчової продукції, яка містить генномодифіковані компоненти, це такі відомі компанії, як Coca-Cola, Nestle, Ferrero, Kraft, Mars, McDonalds, Lipton, Nesquik, Pepsi-Cola. Компанії, що виробляють генномодифіковану сировину, насіння, заходи боротьби з шкідниками та бур'янами : Монсанто, Сінгента, Дюпон, ДауХемикал тощо.

В Україні було прийнято закони і постанови щодо використання генетично модифікованої продукції: Закон України "Про державну систему біобезпеки при створенні, випробуванні, транспортуванні та використанні генетично-модифікованих організмів", прийнятий 31 травня 2007 року, в статті 15 визначається: «Забороняється промислове виробництво та введення в обіг ГМО, а також продукції, виробленої iз застосуванням ГМО, до їх державної реєстрації. Забороняється ввезення на митну територію України ГМО, а також продукції, виробленої із застосуванням ГМО, до їх державної реєстрації, за винятком таких, що призначені для науково-дослідних цілей або дер- жавної апробації» [12]; Постанова Кабінету Міністрів України від 18.02.2009p. №114 «Про затвердження порядку державної реєстрації косметичних та лікарських засобів, джерел харчових продуктів, а також харчових продуктів, які містять генетично модифіковані організми або отримані з їх використанням»[13].

Як показує закордонний досвід, значну роль в обмеженні використання ГМО відіграють громадські рухи екологічного та споживацького спрямування. Саме під їх тиском правлячі кола країн-членів СС розробили свою систему регулювання використання ГМО. В нашій країні подібні рухи поки що започатковані, немає гучних акцій протесту проти ГМО. Це пояснюється низьким рівнем життя населення та комерціалізацією інформаційного простору.

Отже будь-які наукові відкриття може бути використано, як на благо, так і на шкоду людству. А в умовах ринкової економічної системи вони можуть бути використані лише з метою отримання прибутків.

Висновки та перспективи подальших досліджень. Аналіз практики та наслідків використання ГМО дозволяє зробити висновки про їх негативний вплив на продовольчу безпеку, а саме:

1. Вплив на фізичну доступність продовольства: використання ГМО веде до зменшення біологічного різноманіття, що негативно позначається як на асортименті тих харчових продуктів, які вживає людина, так і на біологічному генофонді, який є основою для селекційної роботи.

2. Вплив на економічну доступність продовольства: скорочення асортименту харчових продуктів, яке сприяє зростанню нееластичного попиту та підвищенню цін.

На нашу думку, необхідна заборона на використання ГМО. Недарма в Свропі створюються зони, вільні від ГМО. Такою зоною має стати і Україна.

Перспективи подальшого дослідження проблем впливу ГМО на продовольчу безпеку виходять за межі суто економічного аналізу. Виходячи з того, що доцільність використання ГМО в Україні, враховуючи пї агропромисловий потенціал, 3 нашої точки зору, $\epsilon$ недоречною, необхідною $є$ розробка заходів політико-правового характеру. Неупереджені висновки про наслідки використання ГМО, доцільність їх використання блокуються монополіями, які лобіюють свої бізнес-інтереси. Це $\epsilon$ невід'ємною рисою ринкової економічної системи. Недарма, як показує міжнародний досвід, тільки країни із змішаною економікою спроможні контролювати використання ГМО. Отже, необхідно посилити роль держави, розробляючи відповідні напрямки економічної політики, адже виробники та розповсюджувачі ГМО не мають на меті досягнення продовольчої безпеки, а міжнародні монополії не переймаються національною безпекою. Використання ГМО призводить до витискання значної кількості дрібних національних товаровиробників та монополізації аграрного ринку. 


\title{
Література
}

1. Сорочинський Б. В., Данильченко О. О., Кріпка Г. В. Генетично модифіковані рослини. Київ: Фітосоціоцентр, 2005. 204 с.

2. Генетично модифіковані організми та біобезпека: Огляд основних питань /Автор-упорядник Топчій T.I. Київ, 2004. 22 с.

3. Баласинович Б., Ярошевська Ю. ГМО: виклики сьогодення та досвід правового регулювання. Київ : Видавничий дім “АДЕФ-Україна”, 2010. 256c.

4. Бірта Г.О., Бургу Ю.Г. Генно-модифіковані організми: за і проти: навч. посіб. Київ: Центр учбової літератури, 2017. 128c.

5. Кордзая Н.Р., Сгоров Б.В. Основні поняття продовольчої безпеки країни: монографія. Херсон: Олдіплюс, 2018. 148c.

6. Соколов М. С., Марченко А. І. Потенциальный риск возделывания трансгенных растений и потребления их урожая//Сельскохозяйственная биология. 2002.№5. С. 3-22.

7. Менів О.І. Правове забезпечення використання ГМО при вирощуванні сільськогосподарської продукції рослинного походження в Україні та СС : автореф. дис....канд. юрид. наук : 12.00.06: захист 07.06 .16 / наук. кер. В.Ю. Уркевич. Харків: НЮУ ім. Ярослава Мудрого, 2016. 20 с.

8. Картахенський протокол про біобезпеку до Конвенції про біологічне різноманіття, Протокол ООН 29.01.2000, приєднання - Закон України № 152-IV від 12.09.2002p.URL: http://zakon5.rada.gov.ua/laws/show/995_935?info=1.(lfnf (дата звернення 19.03.19).

9. Гетьман А. П., Лозо В.І. Правове регулювання розвитку біотехнології та використання генетично модифікованих організмів (ГМО) в Свропейському Союзі // Пробл. законності: акад. зб. наук. пр. / Нац. ун-т «Юрид. акад. України ім. Ярослава Мудрого». Харків. 2011. Вип. 117. С. 182.

10. Лейба Л. В. Правові проблеми використання генетично модифікованих організмів при виробництві сільськогосподарської продукції та продуктів харчування // Актуальні проблеми правового забезпечення продовольчої безпеки України: монографія / за ред. В. Ю. Уркевича та М. В. Шульги. Харків: Право, 2013. 326с.

11. Курило В. І., Гиренко І.В. Актуальні питання державного контролю у с сфері забезпечення біобезпеки при поводженні з ГМО у світлі глобалізації проблеми збереження фіторізноманіття // Наук. вісн. нац. унту біоресурсів і природокористування України. Серія «Право»: зб. наук. пр. Київ, 2012. Вип. 173. Ч. 3. С. 208223.

12. Про державну систему біобезпеки при створенні, випробуванні, транспортуванні та використанні генетично модифікованих організмів: Закон України від 31.05.2007 p., № 1103-V6 за станом на 04.10.2018. URL: https://zakon.rada.gov.ua/laws/show/1103-16 (дата звернення 23.03.2019).

13. Про затвердження Порядку державної реєстрації косметичних та лікарських засобів, які містять генетично модифіковані організми або отримані з їх використанням: пост. КМУ від 18.02.2009 р., № 114: за станом на 30.10.2013. URL: https://data.rada.gov.ua/laws/show/114-2009-п (дата звернення 23.03.2019).

Стаття надійшла 30.03.2019

Стаття прийнята до друку 14.04.2019

Доступно в мережі Internet 5.07.2019

\author{
Криницкая О.А. \\ кандидат экономических наук, доцент \\ E-mail: krinitskaia@ukr.net \\ ORCID ID: 0000-0002-5616-2418 \\ Ткачук Т.И.
}

кандидат экономических наук, доцент

кафедра экономической теории и финансово-экономической безопасности Одесская национальная академия пищевых технологий

ул. Канатная, 112, г. Одесса, Украина,65039

E-mail: etfeb@ukr.net

\section{ОЦЕНКА ВЛИЯНИЯ ИСПОЛЬЗОВАНИЯ ГЕНЕТИЧЕСКИ МОДИФИЦИРОВАННОЙ ПРОДУКЦИИ НА СОСТОЯНИЕ ПРОДОВОЛЬСТВЕННОЙ БЕЗОПАСНОСТИ}

В статье рассматриваются экономико-социальные аспекты влияния генетически модифицированной продукции на состояние продовольственной безопасности, в частности фризическую и экономическую доступность продовольствия, предложение продовольственных товаров, ценообразо- 
вание и условия конкуренции. Раскрывается проблема обеспечения человечества продовольствием. Определяются теоретические основы и методика регулирования продовольственной безопасности, а также сущность, причины создания и использования генно - модифицированных организмов в этой системе продовольственной безопасности. Анализируется использование ГМО в мире и отдельных странах в контексте их влияния на продовольственную безопасность. Проанализирована правовая база и методы государственного регулирования генетически модифицированной продукции в разных странах.

Обосновывается необходимость усовершенствования государственного регулирования генетически модифицированной продукции в Украине. Проблема продовольственной безопасности в Украине является острой и взаимосвязанной с кризисным состоянием экономики, ограниченностью материальных, фринансовых и трудовых ресурсов. Украине необходима стратегия развития агропромышленного комплекса с учетом эффективного использования его потенциала, уменьшения импортированной продовольственной продукции с усилением экспортной ориентации. Одним с проблемных вопросов в формировании механизмов развития экологически безопасной окружающей среды является распространение генетически модифицированных организмов (ГМО). В условиях рыночной экономической системы они могут быть использованы только с целью получения прибылей. Использование ГМО влияет на экономическую доступность продовольствия так, как сокращает ассортимент пищевых продуктов и как следствие способствует повышению неэластичного спроса и цен. По нашему мнению, необходим запрет на использование ГМО. Недаром в Европе создаются зоны, свободные от использования ГМО. Такой зоной должна стать и Украина.

Перспективы дальнейших исследований проблем влияния ГМО на продовольственную безопасность выходят за пределы сугубо экономического анализа. Целесообразность использования ГМО в Украине, учитывая ее агропромышленный потенциал, с нашей точки зрения является неуместным, необходима разработка мер политико-правового характера его регулирования.

Ключевые слова: продовольственная безопасность, физическая и экономическая доступность, генетически модифицированная продукция, генентически модифицированные организмы (ГMO).

\author{
Krinitska O. \\ Ph.D., Associate Professor \\ E-mail: krinitskaia@ukr.net \\ ORCID ID: 0000-0002-5616-2418 \\ Tkachuk T. \\ Ph.D., Associate Professor \\ Department of Economic Theory Financial and Economic Security \\ Odessa National Academy of Food Technologies \\ Kanatna str., 112 , Odesa, Ukraine, 65039 \\ E-mail: etfeb@ukr.net
}

\title{
EVALUATION OF THE IMPACT OF USING GENETICALLY MODIFIED PRODUCTS ON FOOD SECURITY CONDITION
}

The article discusses the economic and social aspects of the impact of genetically modified products on the state of food security, in particular the physical and economic accessibility of food, food supply, pricing and competitive conditions. The problem of providing humanity with food is revealed. The theoretical bases and methods of food safety regulation are determined, as well as the essence, the reasons for the creation and use of genetically modified organisms in this food safety system. Use of GMOs in the world and individual countries in the context of their impact on food security has been analyzed. The legal framework and methods of state regulation of genetically modified products in different countries have also been analyzed.

The necessity of improving the state regulation of genetically modified products in Ukraine is substantiated. The problem of food security in Ukraine is acute and interrelated with the crisis state of the economy, limited material, financial and labor resources. Ukraine needs a strategy for the development of the agro-industrial complex, taking into account the effective use of its potential, the reduction of imported food products with an increase in export orientation. One of the problematic issues in formation of the development mechanisms of an ecologically safe environment is the spread of genetically modified organisms (GMOs). In the market economic system, they can only be used for profit. Use of GMOs affects the economic affordability of food as it reduces the range of food products and, as a consequence, contributes to increase of inelastic demand and prices. In our opinion, a ban on use of GMOs is necessary. Not without reason in Europe there are zones free from use of GMOs. Ukraine should become such a zone. 
Prospects for further research on the effects of GMOs on food security go beyond purely economic analysis. The expediency of using GMOs in Ukraine, taking into account its agro-industrial potential, is inappropriate from our point of view, it is necessary to develop measures of its regulation which will have the political and legal nature.

Key words: food security, physical and economic accessibility, genetically modified products, genetically modified organisms (GMOs).

\section{References}

1. Sorochynskyi, B. V., Danylchenko, O. O., \& Kripka, H. V. (2005). Henetychno modyfikovani roslyny. Kyiv: Fitosotsiotsentr.

2. Topchii, T. I. (2004). Henetychno modyfikovani orhanizmy ta biobezpeka: Ohliad osnovnykh pytan. Kyiv.

3. Balasynovych, B., \& Yaroshevska, Yu. (2010). HMO: Vyklyky sohodennia ta dosvid pravovoho rehuliuvannia. Kyiv: Vydavnychyi dim "ADEF-Ukraina".

4. Birta, H. O., \& Burhu, Yu. H. (2017). Henno-modyfikovani orhanizmy. Kyiv: Tsentr uchbovoi literatury.

5. Kordzaia, N. R., \& Yehorov, B. V. (2018). Osnovni poniattia prodovolchoi bezpeky krainy. Kherson: Oldiplius.

6. Sokolov, M. S., \& Marchenko, A. I. (2002). Potentsialnyiy risk vozdelyivaniya transgennyih rasteniy i potrebleniya ih urozhaya. Selskohozyaystvennaya Biologiya, (5), 3-22.

7. Meniv, O. I. (2016). Pravove zabezpechennia vykorystannia HMO pry vyroshchuvanni silskohospodarskoi produktsii roslynnoho pokhodzhennia v Ukraini ta YeS (Doctoral dissertation, NIuU im. Yaroslava Mudroho, 2016) [Abstract]. 1-20. (UMI No. Kand. yuryd. nauk : 12.00.06)

8. Kartakhenskyi protokol pro biobezpeku do Konventsii pro biolohichne riznomanittia, Protokol OON 29.01.2000, pryiednannia - Zakon Ukrainy № 152-IV vid 12.09.2002r. (2002). Retrieved March 19, 2019, from http://zakon5.rada.gov.ua/laws/show/995_935?info=1.(lfnf

9. Hetman, A. P., \& Lozo, V. I. (2011). Pravove rehuliuvannia rozvytku biotekhnolohii ta vykorystannia henetychno modyfikovanykh orhanizmiv (HMO) v Yevropeiskomu Soiuzi. Problemy Zakonnosti,(117), 182.

10. Leiba, L. V. (2013). Pravovi problemy vykorystannia henetychno modyfikovanykh orhanizmiv pry vyrobnytstvi silskohospodarskoi produktsii ta produktiv kharchuvannia. In V. Yu. Urkevycha \& M. V. Shulhy (Eds.), Aktualni problemy pravovoho zabezpechennia prodovolchoi bezpeky Ukrainy. Kharkiv: Pravo.

11. Kurylo, V. I., \& Hyrenko, I. V. (2012). Aktualni pytannia derzhavnoho kontroliu u sferi zabezpechennia biobezpeky pry povodzhenni z HMO u svitli hlobalizatsii problemy zberezhennia fitoriznomanittia. Nauk. Visn. Nats. Un-tu Bioresursiv I Pryrodokorystuvannia Ukrainy, (173 (Ch. 3)), pravo, 208-223.

12. Pro derzhavnu systemu biobezpeky pry stvorenni, vyprobuvanni, transportuvanni ta vykorystanni henetychno modyfikovanykh orhanizmiv: Zakon Ukrainy vid 31.05.2007 r., № 1103-V6 za stanom na 04.10.2018. (2018). Retrieved March 23, 2019, from https://zakon.rada.gov.ua/laws/show/1103-16

13. Pro zatverdzhennia Poriadku derzhavnoi reiestratsii kosmetychnykh ta likarskykh zasobiv, yaki mistiat henetychno modyfikovani orhanizmy abo otrymani z yikh vykorystanniam: Post. KMU vid 18.02.2009 r., № 114: Za stanom na 30.10.2013. (2013). Retrieved March 23, 2019, from https://data.rada.gov.ua/laws/show/114-2009-п

Received 30 March 2019

Approved 14 April 2019

Available in Internet 5.07.2019

Цитування згідно ДСТУ 8302:2015

Криницька О.О., Ткачук Т.І. Оцінка впливу використання генетично модифікованої продукції на стан продовольчої безпеки // Економіка харчової промисловості. 2019. Т. 11, Вип. 2. С. 13-19. doi: 10.15673/fie.v11i2.1390

Cite as APA style citation

Krinitska O. \& Tkachuk T. (2019). Evaluation of the impact of using genetically modified products on food security condition. Food Industry Economics, 11(2), 13-19. doi: 10.15673/fie.v11i2.1390 